\title{
Mobile Phone Utilization for Learning: Physics Teachers' Perception
}

\author{
Agus Suyatna* \\ Graduate Physics Education, Faculty of Teacher Training and Education \\ Universitas Lampung, Indonesia \\ *Corresponding Address: asuyatna@yahoo.com
}

\begin{tabular}{|c|c|}
\hline Article Info & ABSTRACT \\
\hline Article history: & The use of mobile phones for learning is still becoming a debate in \\
\hline $\begin{array}{l}\text { Received: August } 4^{\text {th }}, 2019 \\
\text { Accepted: October } 25^{\text {th }}, 2019 \\
\text { Published: October } 30^{\text {th }}, 2019\end{array}$ & $\begin{array}{l}\text { Indonesia. Many schools forbid their students to bring mobile phones to } \\
\text { school. This study was aimed to describe the perceptions of physics teachers } \\
\text { in Lampung Province regarding the use of mobile phones to study physics. } \\
\text { Data was collected from } 39 \text { physics teachers from various districts in }\end{array}$ \\
\hline $\begin{array}{l}\text { Keywords: } \\
\text { mobile phone utilization; } \\
\text { mobile phone for learning; } \\
\text { physics teacher perceptions. }\end{array}$ & $\begin{array}{l}\text { Lampung Province. The Likert scale with a range of } 1 \text { to } 5 \text { was used. } \\
\text { Descriptive quantitative data analysis was carried out. The results showed } \\
\text { that most teachers agree /strongly agree: (1) to utilize mobile phones in } \\
\text { learning physics both inside and outside of the classroom, (2) the tendency } \\
\text { of students to use mobile phones make the physics learning process } \\
\text { efficient. It could strengthen and improve the quality of the learning process. } \\
\text { Almost all physics teachers agree /strongly agree with mobile phones usage, } \\
\text { because: (1) it could turn the learning process from teacher-centered into } \\
\text { student-centered and from content-oriented learning to process-oriented } \\
\text { learning, (2) it could improve efficiency and productivity in the learning } \\
\text { process. However, they agreed that the use of mobile phones by students } \\
\text { could not replace the teacher's role, so physics teachers needed a more } \\
\text { sophisticated concept of cellular learning to be implemented. }\end{array}$ \\
\hline
\end{tabular}

(C) 2019 Physics Education Department, UIN Raden Intan Lampung, Indonesia.

\section{INTRODUCTION}

In response to $21^{\text {st }}$-century skills such as critical thinking, creative thinking, collaboration, and communication (4C), the instructional model is needed to be innovated (BSNP, 2010). Therefore, various efforts were needed, including providing facilities, systems and learning resources that can optimize student competencies to learn through a scientific approach in accordance with the directives of the 2013 Curriculum. Education in the industrial revolution era 4.0 needs to be carried out in accordance with the characteristics of the millennial generation. They tend to be online and digital platform users, always connected to social media, fast response in capturing information, progressive, like innovation, and high curiosity.

The high demands that previously described were not in line with the empirical facts. Observation results indicated that physics learning in high school was still centered on the teacher. The teacher was still busy explaining and training students to solve problems. The scientific approach was only a lively discussion without optimal realization because teachers still face obstacles. Whereas the scientific approach was considered as a golden bridge to achieve 21st-century skills desired. The results of interviews with several high school physics teachers in Lampung Province showed that teachers still had difficulties in applying the scientific 
approach because of the limited teaching time. We offered the solution to this problem through the mobile learning system as a learning supplement. Many papers also support the use of mobile phones as mlearning devices (Makoe \& Shandu, 2018; Mohammad, 2017; Pujiastuti, 2018; Thinley, Reye, \& Geva, 2014). However, the use of mobile phones both inside and outside the classroom was still becoming a debate in Indonesia. Many schools forbid their students to bring mobile phones to school. Mobile phones are considered to make students distracted and the learning process becomes disrupted.

M-learning is a type of mobile technology learning devices, which is characterized by its existence everywhere. The definition of cellular learning has passed through different perspectives, starting from the perspective that focuses on the technology used for learning to theories that regard mobile learning as studentcentered learning, context, and mobility (Mendez, Mendez, \& Anguita, 2018). Many types of research that already conducted related to m-learning was discussing about mobile-technology devices, student mobility improvement, learning process dynamics, and information transfer (El-Hussein, Osman, \& Cronje, 2010) Android-based mlearning was effectively proved to be used in physics learning so that it affected student learning outcomes become increased (Ahmed \& Parsons, 2013; Taufik \& Kristanto, 2018). A positive correlation between the use of cellular technology and learning outcomes was also investigated, where the use of high cellular technology would create high learning outcomes as well (Zhai, Zhang, Li, \& Zhang, 2019). Besides being able to improve learning outcomes, other research showed that using smartphones on students could help them understand concepts, facilitate argumentation and exchange opinions. The use of m-learning technology was generally considered to be easy and interesting for students (Mendez \& Slisko, 2013). Research conducted on 14-year-old students by comparing learning science using tablets with textbooks and workbooks at school and home, the results show students who learn to use tablets were more intrinsically motivated: interests and satisfaction with the tasks they do, how they see their competency to use the tools needed to learn, and the value of the assignments they do, better than students who use textbooks and workbooks (Mendez, Mendez, \&Anguita, 2018).

The physics m-learning application could be used as a supporting medium for high school students. Other researchers stated the use of media with the Android operating system can be used as a media to support physics learning (Ishak, Astra, Permana, Azizah, Widyanirmala, \& Nugraha, 2014). M-learning can make students learn easier wherever and whenever. Students could access learning materials anytime and anywhere, so students have better concept mastery of learning material. It also makes students feel challenged and it creates a positive learning atmosphere. The m-learning media can be developed with a multimedia format that presents text, images, audio and animation, even experimental simulations and interactive question exercises. Abstract concepts in physics can be visualized with the help of simulations and applied in mlearning to encourage the realization of active, innovative, creative, effective, fun, happy and weighted learning.

The various benefits and advantages of using a mobile phone as described above contradict the regulations of some schools that forbid students to bring mobile phones to school. Therefore, the perception of physics teachers regarding the use of mobile phones for learning becomes very important. This certainly relates to teachers' perceptions about the use of mobile phones for learning. Research on teacher perceptions of mobile phone use has been conducted in Taiwan (Hsieh, \& Tsai, 2017) and in Mumbai India (2017), but in 
Indonesia, especially in physics teachers in Lampung Province, it has never been done. Research on the perception of the use of mobile phones for learning, especially learning physics is very important because it will involve the policy of whether students bring mobile phones to school. Though from the results of the research described above, it is very clear that mobile phones are very useful for learning physics. This study was aimed to describe the perceptions of physics teachers in Lampung Province regarding the use of mobile phones in physics learning.

\section{METHODS}

This research used a quantitative descriptive method to describe the perceptions of physics teachers in Lampung Province regarding the use of mobile phones in physics learning during face-to-face hours, during the outside classroom, and outside of face-to-face hours, both utilization by teachers and students. The teachers that becoming the respondents were teachers from various districts in Lampung Province who already had experience using mobile phones in teaching physics. Data collection instruments were a 1-5 Likert scale questionnaire. Score 1 indicates strongly disagree and score 5 indicates strongly agree. Data were collected using a web-based survey that was sent via WhatsApp to 39 respondents of physics teachers in Lampung Province. Data were analyzed by calculating the frequency of categorized answers for each scale. Respondents' perceptions are inferred from the choice of answers agree and strongly agree. The consistency of perception was examined using a bivariate correlation test among selected perceptions.

\section{RESULTS AND DISCUSSION}

A small proportion $(33.3 \%)$ of physics teachers in Lampung province stated that they used Information and Communication Technology (ICT) very often to study physics while almost half $(48.7 \%)$ stated sometimes. However, there were still $2.6 \%$ of physics teachers who had never used ICT in teaching physics. The perception of physics teachers towards the use of ICT and mobile phones in teaching was presented in Table 1. Almost all respondents (92\%) agreed and strongly agreed to use ICT in teaching physics, both in the form of using mobile phones outside the classroom $(82 \%)$ or inside the classroom $(74 \%)$.

Table 1. Attitudes regarding the use of ICT and mobile phones

\begin{tabular}{llccccc}
\hline No & \multicolumn{1}{c}{ Statement } & SDA & DA & LA & A & SA \\
\hline 1 & Agreement on the use of ICT in teaching physics & $0 \%$ & $0 \%$ & $7.7 \%$ & $56.4 \%$ & $35.9 \%$ \\
\hline 2 & $\begin{array}{l}\text { Approval of students using mobile phones in } \\
\text { learning physics outside class }\end{array}$ & $2.6 \%$ & $2.6 \%$ & $15.4 \%$ & $33.3 \%$ & $48.7 \%$ \\
\hline 3 & $\begin{array}{l}\text { Approval of students using mobile phones in } \\
\text { learning physics in-class hour }\end{array}$ & $0 \%$ & $0 \%$ & $23.1 \%$ & $46.2 \%$ & $28.2 \%$ \\
& Note: & & & & \\
& SDA: Strongly disagree \\
& $\begin{array}{l}\text { DA: Disagree } \\
\text { LA: Less Agree }\end{array}$ \\
A: Agree & & & & \\
SA: Strongly agree & & & & \\
\end{tabular}

Results of the bivariate correlation test showed that there was a low correlation of 0.31 between the frequency of teachers teaching physics with an agreement on the use of ICT in teaching physics, and also a law correlation of 0.28 between the approval of students using mobile phones in learning physics outside hours' classroom with using mobile phones on hours' class. Teachers who often use ICT-based media in the learning process still had not agreed to use mobile phones in the classroom. Physics teacher's perceptions toward the use of ICT was consistent with the perceptions towards 
the use of mobile phones outside the classroom as indicated by the correlation of 0.44 (rather low) between the agreement on the use of ICT in teaching physics with approval of students using mobile phones in learning physics outside class. The results of this study were in line with the results of research on teachers in Kentucky and Tennessee. The study examined the perceptions of 1,121 teachers in Kentucky and Tennessee to determine their support for mobile phone use in the classroom, as well as their perceptions about mobile phone features that were useful for school-related work and teaching barriers to mobile phone.
The results show that there were slightly more teachers who did not support mobile phone use in the classroom compared to those who support their use, with about half more teachers reporting uncertainty. The teachers consider access to the Internet, educational applications, calculators, calendars, and the ability to play podcasts as mobile phone features/functions that are most useful for classroom use. Also, they identified fraud, access to inappropriate information on the Internet, cyberbullying, and disturbances as the main barriers to using mobile phones in the classroom (Thomas, O’Bannon, \& Britt, 2014).

Table 2. Physics teacher's perception of the benefits of using a mobile phone

\begin{tabular}{lllllll}
\hline No & \multicolumn{1}{c}{ Statement } & SDA & DA & LA & A & SA \\
\hline 1 & $\begin{array}{l}\text { The use of mobile phones to learn physics can } \\
\text { meet students' preferences }\end{array}$ & $0 \%$ & $5.1 \%$ & $17.9 \%$ & $51.3 \%$ & $25.6 \%$ \\
\hline 2 & $\begin{array}{l}\text { The use of mobile phones by students to learn, } \\
\text { make the process of learning physics becomes } \\
\text { efficient }\end{array}$ & $0 \%$ & $5.1 \%$ & $17.9 \%$ & $43.6 \%$ & $33.3 \%$ \\
\hline 3 & $\begin{array}{l}\text { The use of mobile phones by students and } \\
\text { teachers strengthens and improves the quality of } \\
\text { the learning process }\end{array}$ & $0 \%$ & $2.6 \%$ & $13.2 \%$ & $55.3 \%$ & $28.9 \%$ \\
\hline
\end{tabular}

The opinions of physics teachers regarding the benefits of using mobile phones are presented in Table 2. More than $75 \%$ of physics teachers agree and strongly agree that the use of mobile phones to learn physics can meet students' preferences. In accordance with the characteristics of the millennial generation, high school students are native users of online/digital platforms, are always connected to social media, are quick to capture information, are progressive, love innovation, and have a high level of curiosity. Through mobile phones, students can access all kinds of teaching materials. Moreover, mobile phones that contain learning applications that are accompanied by games, will certainly better meet the desires of students. The mobile phone was also used not only in physics but also in other subjects, including English. The analysis showed that the performance in vocabulary acquisition and retention by the experimental group using the mobile English vocabulary learning application designed with game-related functions was significantly higher than the control group that did not use the game (Chen, Liu, \& Huang, 2019). Students used their mobile phones to access 2 types of OSRSs (online students' response system): a classic and a game-based OSRS. Student results show that both systems increase participation and involvement. Game-based OSRS is preferred over classic OSRS (Wang, Ran, Huang, \& Swigart, 2019).

More than $75 \%$ of physics teachers agree and strongly agree on the use of mobile phones by students to learn, making the process of learning physics efficient. Teachers can provide teaching materials easily via mobile phones directly, or through Learning System (LMS) mobile learning. M-learning can provide teaching materials, broadcast material, practice questions, exams, virtual application experiments, discussion forums, chat, and even attendance lists. Perhaps because of this fact $84.2 \%$ of physics teachers agreed and 
strongly agreed that the use of mobile phones by students and teachers, strengthens and improves the quality of the learning process. Correlation test results showed the statement of the use of mobile phones by students to learn, make the process of learning physics become efficient correlate 0.76 (moderate) with the belief that the use of mobile phones by students and teachers, strengthens and improves the quality of the learning process. This belief is supported by many research findings which state that $\mathrm{m}$ learning strengthens and improves the quality of the learning process (Khan, Radzuan, Alkhunaizan, Mustafa, \& Khan, 2019; Mughal, Atkins, Morrow, \& Al-Jundi, 2018; Njenga, Oboko, Omwenga, \& Maina, 2018).

Physics teachers' opinions about the role of mobile phones in the physics learning process are presented in Table 3. More than $75 \%$ of teachers agreed and strongly agreed that the use of mobile phones by students and teachers in the physics learning process, breaks away from traditional teaching. This opinion is very much in accordance with the paradigm of learning in the era of the industrial revolution 4.0, namely the use of technology for learning innovation in achieving higherorder thinking skills. Through a variety of media and technology, students and teachers can communicate effectively in various forms and contexts for various purposes. Mobile phones can be used as a means of mobile learning.

Physics teachers agreed (38.5\%) and strongly agreed $(53.8 \%)$ that the use of mobile phones by students expands learning outside of school. Mobile phones can be used to access information without limits. The perception of physics teachers is in line with the opinions of 55 adult learners from four professional groups (9 physicians; 20 nurses; 4 pharmacists; 22 social workers) that digital and cellular technology is emerging as an important resource that supports independent learning for health professionals and human services. The increased use and dependence on this technology has important implications for organizational and workplace policies that can support an effective independent learning process in the digital age (Curran et al., 2019).

Table 3. Physics teacher's perception about the role of mobile phone use

\begin{tabular}{clccccc}
\hline No & \multicolumn{1}{c}{ Statement } & SDA & DA & LA & A & SA \\
\hline 1 & $\begin{array}{l}\text { The use of mobile phones by students and } \\
\text { teachers in the physics learning process breaks } \\
\text { away from traditional teaching }\end{array}$ & $0 \%$ & $7.7 \%$ & $15.4 \%$ & $41 \%$ & $35.9 \%$ \\
\hline 2 & $\begin{array}{l}\text { The use of mobile phones by students expands } \\
\text { learning outside of school }\end{array}$ & $0 \%$ & $0 \%$ & $7.7 \%$ & $38.5 \%$ & $53.8 \%$ \\
\hline 3 & $\begin{array}{l}\text { The use of mobile phones by students can } \\
\text { change the physics learning process from } \\
\text { teacher-centered learning to student-centered } \\
\text { learning }\end{array}$ & $0 \%$ & $0 \%$ & $12.8 \%$ & $41 \%$ & $46.2 \%$ \\
\hline $4 \begin{array}{l}\text { The use of mobile phones by students can } \\
\text { change from content-oriented learning to } \\
\text { process-oriented learning }\end{array}$ & $0 \%$ & $0 \%$ & $10.3 \%$ & $48.7 \%$ & $41 \%$ \\
\hline
\end{tabular}

Almost all respondents have the same perception about mobile phones, namely the use of mobile phones by students, can change the physics learning process from teacher-centered learning to studentcentered learning and can change from content-oriented learning to process- oriented learning. The teacher is no the only source of information for students. Physics teacher's perception in Lampung Province regarding the use of mobile phones for the learning process is in line with the thinking of teachers in Taiwan, according to them, mobile learning: 1) meets student 
preferences, 2) organizes classes with efficiency, 3) strengthens and enhances learning, 4) separates from teaching traditional, 5) centered on student ownership, and 6) expand learning outside of school (Hsieh \& Tsai, 2017). The results of the study to examine the perceptions of 15 teachers and 103 secondary school students in Mumbai, India, show that the majority of teachers $(86 \%)$ and students (92\%) support the use of mobile phones in classrooms while others voice uncertainty. Participants find many mobile phone features useful in the classroom, but the teachers and students are significantly different in their views. Participant responses expressed little concern about most of the obstacles reported in the literature; both teachers and students are not too worried about mobile phone use which causes learning disruptions c. Physics teacher's suggestions regarding the use of mobile phones for the learning process are presented in Table 4.

Table 4. Suggestions of physics teachers regarding the use of mobile phones for the learning process

\begin{tabular}{llccccc}
\hline No & \multicolumn{1}{c}{ Statement } & SDA & DA & LA & A & SA \\
\hline 1 & $\begin{array}{l}\text { I suggest the use of technology in learning } \\
\text { physics especially to improve efficiency and } \\
\text { productivity }\end{array}$ & $0 \%$ & $0 \%$ & $0 \%$ & $56.4 \%$ & $43.6 \%$ \\
\hline 2 & $\begin{array}{l}\text { Need to develop more sophisticated mobile } \\
\text { learning concepts among teachers }\end{array}$ & $0 \%$ & $2.6 \%$ & $5.1 \%$ & $35.9 \%$ & $56.4 \%$ \\
\hline 3 & $\begin{array}{l}\text { The use of mobile phones by students in the } \\
\text { learning process cannot replace the teacher's role }\end{array}$ & $0 \%$ & $0 \%$ & $7.7 \%$ & $30.8 \%$ & $61.5 \%$ \\
\hline
\end{tabular}

Teachers who think that students 'use of mobile phones can change from teachercentered learning to student-centered and students' use of mobile phones can change from content-oriented learning to learningoriented processes, suggesting the use of technology in physics learning especially to improve efficiency and productivity. Physics teachers who agreed and strongly agreed that students use mobile phones to study physics outside of face-to-face hours and in face-to-face hours in class suggested that it was necessary to develop more sophisticated cellular learning concepts among teachers. The opinions of physics teachers are in line with what is recommended by (Hsieh \& Tsai, 2017)so that mobile devices can use transformative power in learning, it may be necessary to develop more sophisticated mobile learning concepts among teachers.

\section{CONCLUSION}

Based on the results of data analysis, most teachers agreed/strongly agreed: (1) to utilize mobile phones in learning physics both inside and outside classroom, (2) the tendency of students to use mobile phones make the physics learning process efficient, it could strengthen and improve the quality of the learning process. Almost all physics teachers agree /strongly agree with mobile phones usage, because: (1) it could turn the learning process from teacher-centered into student-centered and from content-oriented learning to process-oriented learning, (2) it could improve efficiency and productivity in the learning process. Almost all physics teachers agree/strongly agree to recommend the use of technology in physics learning especially to improve efficiency and productivity, and state that it is necessary to develop more sophisticated cellular learning concepts among teachers. However, they agreed that the use of mobile phones by students in the learning process could not replace the teacher's role. Teachers' perceptions about the benefits of mobile phones in the learning process are positively correlated with the commitment to use mobile phones to improve the quality of the learning process and learning outcomes. 
It is recommended that principals in high schools do not prohibit their students from bringing mobile phones to school as long as they are used for learning. Teachers should learn various mobile phone-based learning applications to optimize learning for students.

\section{ACKNOWLEDGMENT}

Thanks to the Director of Research and Community Service (DRPM) who has funded this research and thanks also to physics teachers who were willing to be respondents.

\section{REFERENCES}

Ahmed, S., \& Parsons, D. (2013). Abductive Science Inquiry using Mobile Devices in The Classroom. Computers and Education, 63, 62-72. https://doi.org/10.1016/j.compedu.2012 .11 .017

BSNP. (2010). Pengembangan Paradigma Pendidikan Nasional Abad XXI. Retrieved from http://www.bsnpindonesia.org/id/wpcontent/uploads/2012/04/LaporanBSNP-2010.pdf

Chen, C. M., Liu, H., \& Huang, H. Bin. (2019). Effects of a Mobile GameBased English Vocabulary Learning App on Learners' Perceptions and Learning Performance: A Case Study of Taiwanese EFL Learners. ReCALL, 31(2), 170-188. https://doi.org/10.1017/S09583440180 00228

Curran, V., Gustafson, D. L., Simmons, K., Lannon, H., Wang, C., Garmsiri, M., ... Wetsch, L. (2019). Adult Learners' Perceptions of Self-Directed Learning and Digital Technology Usage in Continuing Professional Education: An Update For The Digital Age. Journal of Adult and Continuing Education, 25(1), 74-93.

https://doi.org/10.1177/1477971419827 318

El-Hussein, M., Osman, M., \& Cronje, J. C.
(2010). Defining Mobile Learning in the Higher Education Landscape. Journal of Educational Technology \& Society, 13(3).

Hsieh, W. M., \& Tsai, C. C. (2017). Taiwanese High School Teachers' Conceptions of Mobile Learning. Computers and Education, 115, 82-95. https://doi.org/10.1016/j.compedu.2017 .07 .013

Ishak, G. A., Astra, I. M., Permana, A. H., Azizah, N., Widyanirmala, W., \& Nugraha, A. (2014). Pengembangan Media Cerita Gelombang Elektromagnetik Melalui Mobile Learning Dengan Sistem Operasi Android. Prosiding Seminar Nasional Fisika, 57-61.

Khan, R. M. I., Radzuan, N. R. M., Alkhunaizan, A. S., Mustafa, G., \& Khan, I. (2019). The Efficacy of MALL Instruction in Business English Learning. International Journal of Interactive Mobile Technologies, 13(8), 60-73.

Makoe, M., \& Shandu, T. (2018). Developing a Mobile App for Learning English Vocabulary In An Open Distance Learning Context. International Review of Research in Open and Distance Learning, 19(4), 208-221. https://doi.org/10.19173/irrodl.v19i4.37 46

Mendez, D., Mendez, M., \& Anguita, J. (2018). Motivation of 14 year-old Students using Tablets, Compared to Those using Textbooks and Workbooks. International Journal of Interactive Mobile Technologies, 12(4), 86-96.

https://doi.org/10.3991/ijim.v12i4.9203

Mendez, D., \& Slisko, J. (2013). Software Socrative and Smartphones as Tools for Implementation of Basic Processes of Active Physics Learning in Classroom: An Initial Feasibility Study with Prospective Teachers. European Journal of Physics Education, 4(2), 17- 
24

Mohammad, M. A. H. (2017). Mobile Applications' Impact on Student Performance and Satisfaction. The Turkish Online Journal of Educational Technology, 14(4), 102-112.

Mughal, N. A., Atkins, E. R., Morrow, D., \& Al-Jundi, W. (2018). Smartphone Learning as an Adjunct to Vascular Teaching - A Pilot Project. BMC Medical Education, 18(1), 1-6. https://doi.org/10.1186/s12909-0181148-8

Njenga, S., Oboko, R., Omwenga, E., \& Maina, E. (2018). Facilitating Group Learner Participation using Intelligent Agents in Collaborative M-Learning. 2018 IST-Africa Week Conference, IST-Africa 2018, 1.

Pujiastuti, H. (2018). Interactive Teaching Materials Based on Scientific Approach: Triangles and Quadrilaterals. SHS Web of Conferences, 42, 00097. https://doi.org/10.1051/shsconf/201842 00097

Taufik, M., \& Kristanto, A. (2018). Pengembangan Mobile Learning Berbasis Aplikasi Android Mata Pelajaran Fisika Materi Listrik Arus Searah Kelas XI SMK Negeri 2 Kediri. Jurnal Mahasiswa Teknologi Pendidikan, 9(2), 1-8.
Thinley, P., Reye, J., \& Geva, S. (2014). Tablets (iPad) for M-Learning in the Context of Social Constructivism to Institute an Effective Learning Environment. International Journal of Interactive Mobile Technologies, 8(1), 16-20. https://doi.org/10.3991/ijim.v8i1.3452

Thomas, K. M., O'Bannon, B. W., \& Britt, V. G. (2014). Standing in the Schoolhouse Door: Teacher Perceptions of Mobile Phones in The Classroom. Journal of Research on Technology in Education, 46(4), 373395.

https://doi.org/10.1080/15391523.2014. 925686

Wang, W., Ran, S., Huang, L., \& Swigart, V. (2019). Student Perceptions of Classic and Game-Based Online Student Response Systems. Nurse Educator, 44(4), E6-E9. https://doi.org/10.1097/NNE.00000000 00000591

Zhai, X., Zhang, M., Li, M., \& Zhang, X. (2019). Understanding the Relationship Between Levels of Mobile Technology use in High School Physics Classrooms and The Learning Outcome. British Journal of Educational Technology, 50(2), 750-766. https://doi.org/10.1111/bjet.12700 